\begin{tabular}{|c|c|}
\hline Title & $\begin{array}{l}\text { Reconsidering directly elected mayors in Ireland: Experiences } \\
\text { from the United Kingdom and America }\end{array}$ \\
\hline Authors & Quinlivan, Aodh \\
\hline Publication date & $2008-11$ \\
\hline Original Citation & $\begin{array}{l}\text { Quinlivan, A., 2008. Reconsidering Directly Elected Mayors in } \\
\text { Ireland: Experiences from the United Kingdom and America. } \\
\text { Local Government Studies, 34(5), pp.609-623. }\end{array}$ \\
\hline Type of publication & Article (peer-reviewed) \\
\hline $\begin{array}{l}\text { Link to publisher's } \\
\text { version }\end{array}$ & $\begin{array}{l}\text { http://www.informaworld.com/smpp/section? } \\
\text { content=a904520116\&fulltext=713240928 - } \\
\text { 10.1080/03003930802413814 }\end{array}$ \\
\hline Download date & 2023-04-26 15:16:08 \\
\hline $\begin{array}{l}\text { Item downloaded } \\
\text { from }\end{array}$ & http://hdl.handle.net/10468/25 \\
\hline
\end{tabular}

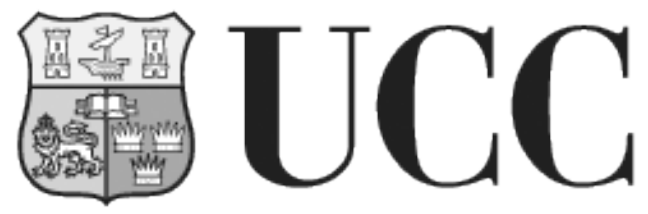

University College Cork, Ireland

Coláiste na hOllscoile Corcaigh 


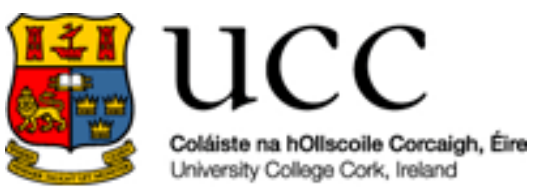

This is an electronic version of an article published:

Quinlivan, A., 2008. Reconsidering Directly Elected Mayors in Ireland: Experiences from the United Kingdom and America. Local Government Studies, 34(5), pp.609-623. doi: 10.1080/03003930802413814

Local Government Studies is available online at informaworldTM : http://www.informaworld.com/smpp/title content=t713673447

http://hdl.handle.net/10468/20 


\title{
Reconsidering Directly Elected Mayors in Ireland: Experiences from the United Kingdom and America
}

\author{
AODH QUINLIVAN \\ Department of Government, University College Cork, Ireland.
}

As part of the proposed modernisation of Irish local government a directly elected mayor with executive powers will be introduced in Dublin in 2011. It is then anticipated that the system of elected mayors will be extended to the whole country. However, it is not known what impact this new form of executive leadership will have on the prevailing system whereby city and county managers are dominant. Drawing from experiences in the United Kingdom and the United States, this paper suggests that Ireland needs a clear, unambiguous mayoral model. As a political leader with executive powers it is imperative that the mayor's relationships with both the council and the city/county manager are tightly defined.

\section{Introduction}

In their recent article, Magre and Bertrana (2007: 181) refer to institutional reforms in local government in Western Europe which have led to significant changes in interorganic relations and the introduction, in some countries, of directly-elected mayors. They cite Italy, England, Austria, Germany, Greece and Portugal and examine the institutional convergence in the six countries. The article reflects the fact that the office of executive mayor has become a prominent feature of local government in Europe (Elcock and Fenwick, 2007; Denters and Rose, 2005; Schaap and Ringeling, 2003). Ireland also proposed to go down the route of direct mayoral elections and the initiative was legislated for in the Local Government Act, 2001 (to be effective from the next set of local elections in June 2004). However, in a bizarre shifting of positions in 2003, the Government repealed the directly elected mayor proposal from the 2001 Act. In presenting the Local Government Bill, 2003 to the Irish Senate on 26 February, Minister Martin Cullen explained that he was planning major changes to the local government system. Once these changes had time to 'bed down' the issue of the mayor's election and role would be reconsidered (Cullen, 2003). Since then a debate has rumbled on as to 
whether Ireland should have directly elected mayors. In the build-up to the 2007 General Election, Green Party leader Trevor Sargent announced that his party, in government, would introduce directly elected mayors to make local government democratically accountable. The Fine Gael and Labour Party manifestos also contained a pledge to introduce directly elected mayors. Following the election, a coalition government was formed with Fianna Fáil, the Green Party and the Progressive Democrats. The three parties produced a Programme for Government which pledges to introduce a directly elected mayor for Dublin with executive powers by 2011. In addition, the Government has promised a Green Paper on Local Government Reform which will address the issue of directly elected mayors.

This article evaluates the proposal to introduce directly elected mayors in Ireland and draws on experiences to date in the United Kingdom and America. The analysis is partly based on interviews with five strong mayors in New York State, in the cities of Albany, Troy, Schenectady, Syracuse and Utica. Detailed semi-structured interviews were also conducted other local government officials, council members, stakeholders and citizens.

\section{United Kingdom}

Former British Prime Minister, Tony Blair, oversaw the introduction of directly elected mayors in the United Kingdom, via the Local Government Act, 2000. Bearing Blair's explicit personal support the White Paper, Modern Local Government - In Touch with the People (1998) highlighted the lack of clear political leadership in the UK local government system (Orr, 2004). The White Paper drew attention to a leadership deficit at the local level and a culture of apathy about local democracy which contributed to an average turnout at local elections of forty per cent or below. The Government promoted the concept of directly elected mayors, stressing speed of decision-making, greater accountability and a renewal of interest in local government. The Government's enthusiasm for the idea can be seen in the way that the Local Government Act, 2000 described by Chandler as one of the most important reforms of local authority powers and policy-making structures of the last one hundred years - was weighted in favour of elected mayors (Wilson and Game, 2006). Three main options for executive arrangements in councils with populations in excess of 85,000 were presented, two of which involved the direct election of mayors.

Option 1 - Mayor and Cabinet: A directly elected mayor who appoints an executive cabinet of councillors.

Option 2 - Leader and Cabinet: An executive leader, elected by the full council, with a cabinet of councillors, either appointed by the leader or elected by the council.

Option 3 - Mayor and Manager - A directly elected mayor with a day-to-day officer appointed by the council. 
Orr (2004: 337) makes the point that a difficulty with the legislation was 'the marked absence of a clear mayoral model.' Under the mayor and cabinet option the directly-elected mayor would head a political executive with a wide-range of decisionmaking powers and would be responsible for proposing policy and preparing the budget (Copus, 2004). However, under the mayor and manager option, most executive power would rest with the manager. Wilson and Game (2006: 103) correctly note that this option suffered from a 'double handicap' as county or city managers did not exist in the UK system.

Amongst councillors there was little support for the introduction of directlyelected mayors on the basis that putting significant powers in the hands of one person would be unwise. The leader and cabinet model seemed a safer option. The council would appoint one of its members as the executive leader and she/he would, in turn, be supported by cabinet. The remaining councillors - effectively backbenchers - would scrutinise the activities of the executive and focus on representational work.

Under the provisions of the 2000 Act, if a local authority chose one of the two directly-elected mayor options it would have to get local approval through a referendum. A petition in favour of one of the mayoral models, signed by more than five per cent of the local electorate, could also trigger a referendum. The first local authority to hold such a referendum was Berwick-upon-Tweed following a petition from the local electorate. However, the proposal to have a directly-elected mayor was strongly rejected in the referendum. This was to prove a bad omen for Blair and the Labour Party. Over the period of 2001-2006, thirty-three mayoral referendums were held in the UK, ten of which were initiated by petitions. Twelve of the referendums were passed; in the remaining twenty-one cases people rejected the introduction of directly-elected mayors. The referendum vote in Sunderland in 2001 had a turnout of ten per cent; the following year in Southwark eleven per cent of the electorate voted (see Wilson and Game, 2006: 106 and the UK Electoral Commission, http://www.electoralcommission.org.uk/).

Orr (2004: 342) claims that the mayoral referendums and elections have not raised the visibility of local government except 'in faintly embarrassing ways.' In mayoral elections the electorate has tended to vote against the established political parties, instead opting for fringe candidates and independents. Ray 'Robocop' Mallon, a police Detective Superintendent and former captain of the Great Britain water polo team, enjoyed a striking election success in Middlesbrough. In Hartlepool, the local soccer mascot, H'Angus the Monkey (Stuart Drummond) successfully stood for election using the slogan 'Vote H'Angus: he gives a monkeys.' The main political parties appear to be losing their grip on an apathetic electorate who need to be shocked into voting. John (2004: 51) asserts that, on occasions, the local electorate 'sometimes demanded the mayoral option in order to express their dissatisfaction with the local Labour Party machines.'

Latham (2002) describes the mayoral elections as an unmitigated disaster for New Labour and Elcock and Fenwick (2007: 228) note that the national Labour leadership has lost interest in the mayoral agenda. With only twelve of thirty-three referendums leading to mayoral elections it is clear that the British public do not support the concept. Mallon and Drummond have enjoyed successes as local change agents but, overall, the directlyelected mayors in the UK have not emerged as force for wider local government reform (Orr, 2004). According to Sandford (2004) elected mayors only constitute 'an internal 
reform to the governance process of a local authority' and are not a panacea for local government reinvigoration.

\section{United States of America}

The local government system in the USA is noted for its fragmentation (Savitch and Vogel, 2005). This is primarily due to the fact that local government is established by the states rather than by the federal government. Accordingly, 'there are fifty systems of local government, not just one' (Savitch and Vogel, 2005: 213). With about eighty per cent of American citizens now living in cities, suburbs of cities, or towns, it is clear that city government is the focal point for the provision of services - police, sanitation, housing, public transport. In broad terms, there are three forms of city government in existence (Swift, 2003).

\section{Mayor-Council Model}

This system is based on a separation of powers between the executive (mayor) and the legislature (council). The mayor is directly elected by the people in accordance with the city's charter. In the weak-mayor version, the mayor has limited powers and lacks a veto. Accordingly the council is dominant in the decision-making process. The more popular strong-mayor variant shifts the power towards the mayor who appoints and removes heads of departments, prepares the budget and uses the power of veto.

\section{Council-Manager Model}

This system is based on the corporate model, whereby voters (shareholders) elect councillors (board of directors) who appoint a city manager (chief executive officer). The city manger has day-to-day responsibility for running the city (Savitch and Vogel, 2005). The council sets policy and the manager, through her/his staff, implements the council's policies in a professional manner. This system operates in Ireland and has its roots in the classical politics-administration dichotomy.

\section{The Commission Model}

This system is rarely used and is based on the notion that one group (typically three to seven members) combine the executive and legislative dimensions. All members are elected and, subsequently, each is responsible for at least one city department. The commissioners elect a chairperson (sometimes called mayor) from the group but she/he has no extra powers.

The mayor-council and the council-manager are the dominant forms of local government in the United States. Presently, the council-manager model is used in forty-nine per cent of local authorities; the mayor-council model is used in forty-four per cent of authorities. As Savitch and Vogel (2005: 218) correctly point out, the two models 'represent two distinct views about the purpose of city government.' The primary purpose of local government, as seen from the suburbs, is the provision of basic public services. Politics is regarded as 'antithetical to good governance' (ibid.). The view within cities, especially 
larger ones, is that local government is more than service provision, and visible political leadership is essential.

As part of ongoing research into the topic of directly elected mayors, five strong mayors from the following cities in New York State were interviewed between September and November 2006.

\begin{tabular}{|l|c|l|l|l|}
\hline \multicolumn{1}{|c|}{ CITY } & POPULATION & \multicolumn{1}{c|}{ MAYOR } & \multicolumn{1}{c|}{ PARTY } & \multicolumn{1}{c|}{ TERM } \\
\hline Albany & 93,919 & Gerald Jennings & Democrat & In $4^{\text {th }}$ term \\
\hline Syracuse & 144,001 & Matthew Driscoll & Democrat & In $2^{\text {nd }}$ term \\
\hline Utica & 59,485 & Tim Julian & Republican & In $2^{\text {nd }}$ term \\
\hline Troy & 48,649 & Harry Tutunjian & Republican & In $1^{\text {st }}$ term \\
\hline Schenectady & 61,016 & Brian Stratton & Democrat & In $1^{\text {st }}$ term \\
\hline
\end{tabular}

* Population figures from the US Census Bureau.

Not surprisingly, all five supported the mayor-council models and cited the fact that they were directly elected by and accountable to the people. Mayor Tutunjian explained that the people of Troy had voted in 1995 to move from the council-manager model to the mayor-council one. He stated:-

The city manager system was not working that well. There was no real accountability. The managers were accountable to the council, not so much to the citizens of Troy [...] it's one thing to be an employee of the city, it's another thing to be elected by the people and have your job on the basis of an election. I'm pretty hands-on. I'm very public. I've made my reputation on going to major fires, crime scenes and out with the snow ploughs in the winter time. It's to be visible. I see my role as being a visible cheerleader for the city.

Mayor Jennings, who has been Albany's first citizen since 1993, echoed the sentiments of his counterpart in Troy,

It stops with me. I'm the person who has to make the tough decisions and do the budgets and everything else. People know that, in the city of Albany, if something is happening or if you want something, you go to the mayor's office as opposed to having fifteen or sixteen councillors. Then you are held accountable every four years [...] this is a business I run; I micro-manage. My style is too aggressive for some but I'm $24 / 7$ on the job. I want to know what is going on. I am the CEO of the city.

Mayor Stratton at least offered some balance. When he became mayor of Schenectady in 2004 he inherited "a fiscal train wreck." The previous strong mayor had bankrupted the city with a projected $\$ 10$ million deficit and a rock bottom credit rating. Mayor Stratton observed: 
I was a council member during the previous term but when you are a part-time council member you defer or assume that the full time leadership knows what they are doing. You are spoon-fed all the information. We had a mayor that did dome outrageous things [...] the strong mayor is accountable to the people. The danger is that in city government and local government there are so many challenges that you need somebody who knows what they are doing. The election process, while it's more fair, also affords the opportunity to have somebody elected by their popularity, by a political party and they may not be the absolute best person for the job.

The relationship with the legislature (council) is one of the key considerations in the mayor-council model. While Mayor Driscoll in Syracuse attends the meetings of the city council and fosters a partnership relationship with the legislature, it seems that the council members are only as influential as the mayor allows them to be. In Utica, Mayor Julian admits that the council does 'not have a lot of power.' The mayor prepares the annual budget and presents it to city council. The council either approves the budget or suggests changes. However, Mayor Julian can choose to ignore the suggestions of council and proceed with his initial budget. Albany's Mayor Jennings made it clear that he worked independently of the council - 'I'm not obliged to go to council meetings, thank God.'

Helen Desfosses served as President of the Albany City Council from 1997 to 2005. She feels that Albany has a strong mayor system 'to the point of absurdity.' Equally, one former city councillor noted:

The mayor is a very vindictive individual with a 'King of the Mountain' attitude who treats the council with disdain. I left because I had so little to work with. The mayor is all powerful and the council members are petrified of him.

While local government in America is fragmented, more and more cities, counties and towns are shifting to the council-manager model. Professor Robert McEvoy of the Nelson A. Rockefeller College of Public Affairs and Policy at the University of Albany, served as the Chief Executive Officer of Schenectady County for twenty-two years. He explained during an interview:

Mayors do not have to have any qualifications. By contrast, managers are professionally trained administrators. Our parent body, the ICMA (International City/County Management Association) requires city and county managers to have a Masters degree in Public Administration and at least seven years experience in a town. The concept of a 'strong mayor' is a misnomer. The strongest mayors are those who are policy initiators without the council-manager model.

Academic literature in America tends to support the council-manager approach. Folz and French (2005: 42) note: 
City managers appear to be more likely than mayors to consult with key stakeholders before they reach a decision that affects a local service or project.

Svara (1990) has observed that the mayor-council form experiences more conflict while the council-manager governments are typically more cooperative.

\section{Ireland}

Local government in Ireland is highly centralised (Roche, 1982; Barrington, 1991; Quinlivan, 2000; Haslam, 2003; Callanan and Keogan, 2003) and general subordination to central government has been a dominant theme since the foundation of the State in 1922. In particular, local authorities are very dependent on the centre for finance as they have limited revenue raising capabilities (Dollard, 2003; Quinlivan, 2004). The local government system is based on the classical separation of powers. The elected members have responsibility for reserved functions, whereby they formulate the policy framework for the local authority. All functions which are not stated in law as being reserved functions are automatically deemed executive functions and are the responsibility of the appointed city/county manager.

A cursory glance at the Irish system would lead one to conclude that it operates in accordance with the politics/administration dichotomy. The elected members formulate policy and the manager is responsible for implementation and the day-to-day running of the authority. The reality is somewhat different as the legal separation of powers is not respected. The elected members will try to influence the manager with regard to executive decisions while it has long been recognised that the manager is the major initiator of policy (Collins, 1987; Sheehy, 2003; Quinlivan, 2006; Zimmerman, 2006).

Despite the lack of adherence to the legal definition of roles the Irish system works relatively well. In most local authorities, the elected members and the manager form an effective partnership. Zimmerman (2006) uses Lindblom's 'Mutual Adjustment Theory' to explain how local government operates in Ireland. Simply stated, the elected members and the manager 'coordinate with each other ... without rules that fully describe their relations to each other' (Zimmerman, 2006: 197). Essentially, the local government manager in Ireland plays the role of both the 'classical' and 'political' bureaucrat as described by Klausen and Magnier (1998). 


\begin{tabular}{|ll|}
\hline \multicolumn{2}{|c|}{ The classical and political bureaucrat model } \\
(Klausen and Magnier, 1998, as adapted by Hambleton, 2005). \\
Classical Bureaucrat & Political Bureaucrat \\
$\begin{array}{l}\text { Guide subordinate staff in day-to-day } \\
\text { handling of activities. }\end{array}$ & Formulate ideas and visions. \\
$\begin{array}{l}\text { Manage economic affairs, accounts and } \\
\text { budgetary control. }\end{array}$ & $\begin{array}{l}\text { Promote and encourage new projects in the } \\
\text { community. }\end{array}$ \\
$\begin{array}{l}\text { Ensure that rules and regulations are } \\
\text { followed. }\end{array}$ & $\begin{array}{l}\text { Provide the mayor and council with } \\
\text { political advice. }\end{array}$ \\
$\begin{array}{l}\text { Provide the mayor and council with legal, } \\
\text { economic and other kinds of technical } \\
\text { advice. }\end{array}$ & $\begin{array}{l}\text { Be informed about citizens' viewpoints. } \\
\text { Develop and implement norms concerning the } \\
\text { proper roles of politicians vis-à-vis bureaucrats. }\end{array}$ \\
& $\begin{array}{l}\text { Influence decision-making processes in order to } \\
\text { secure sensible and efficient solutions. }\end{array}$ \\
\hline
\end{tabular}

Within this system of mutual adjustment, each local authority elects a mayor on an annual basis from among its own members. ${ }^{1}$ It is usually the case that the position of mayor is agreed in advance as part of a pact between the main political parties. Kenny (2004: 15) notes that the mayoralty 'is rotated among party members with one taking the chair for a year at a time.' The office of mayor is largely a ceremonial one and the incumbent does not have any significant additional powers in comparison to the regular elected members.

It is now proposed by the Irish Government that the office of mayor will change drastically. Beginning in Dublin in 2011, a mayor with executive powers will be directly elected by the people of the city, presumably for a five year term (as per the initial legislation in 2001). Legislation governing the direct election of mayors will not be produced until 2008 and so it is not known what the precise functions of the mayor will be and how the office will impinge on the role currently played by the city/county manager. In drafting the legislation it is hoped that the experiences of the United States and the United Kingdom will be taken into consideration, in particular the following points:-

- Directly elected mayors increase the visibility of local government and, according to Elcock and Fenwick (2007: 236) effective mayors provide an 'accountable focal point for other local actors, including neighbouring local governments, businesses and voluntary agencies.'

\footnotetext{
${ }^{1}$ The title Lord Mayor is used in Dublin city and Cork city. Some county councils and town councils use the Irish title ‘Cathaoirleach’ meaning chairman.
} 
- Directly elected mayors with executive powers (especially the 'strong' variation in America) can make quicker decisions and cut through much of the traditional internal local government bureaucracy.

- Placing too much power in the hands of one individual can lead to corrupt practices. For the most part, Ireland has been served well by the management system whereby the city/county managers are the dominant figures. Professor Joseph Zimmerman, presently based in the University of Albany, noted during an interview with the author:

The Irish management system has worked very well. Some managers have been better than others, of course, but, overall, they have been very good. Managers have not been involved in corruption or scandal. Many mayors in America have been involved in scandals.

This point is well made. Local authority managers are an important grouping. Collins (1987: 3) states that 'the name, face and impact of their local manager is better known to the average Irish citizen than any other non-elected official.' The office of city/county manager is highly regarded and is noted within Irish public administration for probity and integrity.

- Renewal of interest in local government was one of the main motivations for the introduction of directly elected mayors in the United Kingdom. However, evidence to date shows that public interest and involvement have not increased (see Elcock and Fenwick, 2007).

\section{Conclusion}

The direct election of a mayor for Dublin in 2011 is expected to herald the extension of the system shortly afterwards to the entire country. The one lesson Ireland can learn from the United Kingdom is that it is essential to create a clear, unambiguous mayoral model. The arrangements introduced in the UK offered too many options and, as previously mentioned, suffered from a 'double handicap' as the office of city/county manager did not previously exist. The main lesson to be learned from the United States is the importance of clarifying relationships. As a political figure with some executive powers the Irish mayor will have to work closely will both the legislature (council) and the executive (manager). The devil is in the detail and unless the Irish legislation clearly outlines the division of executive powers with the manager, there is a danger that the office of mayor will be an empty role.

The local government system in Ireland needs urgent reform and the introduction of directly elected mayors is only one element of that process. The starting point must be devolution of powers and financial autonomy from central government to local authorities. This would allow mayors and councillors to exercise their reserved policy 
powers and work in partnership with a professional manager. Whether the mayors in question are directly or indirectly elected is a secondary consideration. 


\section{References}

Barrington, T. (1991), 'Local Government in Ireland' in R. Batley and G. Stoker (eds.), Local Government in Europe: Trends and Developments, pp.155-169, Houndmills, Basingstoke: Macmillan Press.

Callanan, M. and Keogan, J.F. (2003) (eds.), Local Government in Ireland: Inside Out, Dublin: Institute of Public Administration.

Chandler, J.A. (2001), Local Government Today ( ${ }^{\text {rd }}$ edition), Manchester: Manchester University Press.

Collins, N. (1987), Local Government Managers at Work, Dublin: Institute of Public Administration.

Copus, C. (2004), 'Directly Elected Mayors: A Tonic for Local Governance or Old Wine in New Bottles?' Local Government Studies, Vol.30, No.4, pp.576-588.

Cullen, M. (2003), Speech in Seanad Éireann at the second stage debate of the Local Government Bill 2003, 26 February.

Denters, B. and Rose, L.E. (eds.) (2005), Comparing Local Governance: Trends and Developments, Houndmills, Basingstoke: Palgrave Macmillan.

Dollard, G. (2003), 'Local Government Finance: The Policy Context' in M. Callanan and J.F. Keogan (eds.), Local Government in Ireland: Inside Out, pp.325-340, Dublin: Institute of Public Administration.

Elcock, H. and Fenwick, J. (2007), 'Comparing Elected Mayors', International Journal of Public Sector Management, Vol. 20, No. 3, pp.226-238.

Haslam, R. (2003), 'The Origins of Irish Local Government' in M. Callanan and J.F. Keogan (eds.), Local Government in Ireland: Inside Out, pp.14-40, Dublin: Institute of Public Administration.

Folz, D.H. and French, E. (2005), Managing America's Small Communities - People, Politics and Performance, New York: Rowman and Littlefield.

Hambleton, R. (2005), 'Leading Localities - Rethinking the Agenda' in M. Haus, H. Heinelt and M. Stewart (eds.), Urban Governance and Democracy, Abingdon: Routledge.

John, P. (2004), 'Strengthening political leadership? More than mayors', in G. Stoker and D. Wilson (eds.), British Local Government in the $21^{\text {st }}$ Century, pp.43-59, Houndmills, Basingstoke: Palgrave Macmillan.

Kenny, L. (2004), From Ballot Box to Council Chamber: A Guide to Ireland's County, City and Town Councillors 2004-2009, Dublin: Institute of Public Administration.

Klausen, K.K. and Magnier, A. (1998), The Anonymous Leader: Appointed Chief Executive Officers in Western Local Government, Odense: Odense University Press.

Latham, P. (2002), New Labour's US-Style Executive Mayors: The Private Contractors' Panacea, London: GMB Public Services Section/ Labour Campaign for Open Local Government/Socialist Renewal.

Lindblom, C.E. (1965), The Intelligence of Democracy: Decision Making Through Mutual Adjustment, New York: Free Press.

Magre, J. and Bertrana, X. (2007), Exploring the Limits of Institutional Change: The Direct Election of Mayors in Western Europe, Local Government Studies, 33 (2), pp. 181-194. 
Orr, K. (2004), 'If Mayors are the Answer then what was the Question?' Local Government Studies, vol. 30, no. 3, pp.331-344.

Quinlivan, A. (2000), 'Local Government Bill, 2000 - Implications for Municipal Authorities. Another False Pregnancy?’ Administration, Vol.48, No3, pp.10-20.

Quinlivan, A. (2004), 'Local Government Finance in a Wider Context', Paper presented at Annual National Forum of the Chambers of Commerce of Ireland, Reform of Local Government Financing - Value for Money and Effectiveness, Seven Oaks Hotel, Carlow, November 2004.

Quinlivan, A. (2006), Philip Monahan - A Man Apart: The Life and Times of Ireland's First Local Authority Manager, Dublin: Institute of Public Administration.

Roche, D. (1982), Local Government in Ireland, Dublin: Institute of Public Administration.

Sandford, M. (2004), 'Elected Mayors I: Political Innovation, Electoral Systems and Revitalising Democracy’, Local Government Studies, Vol.30, No.1, pp.1-21.

Savitch. H.V. and Vogel, R.K. (2005), 'The United States: executive-centred politics', in B. Denters and L.E. Rose (eds.), Comparing Local Governance, Houndmills, Basingstoke: Palgrave Macmillan.

Schaap, I. and Ringeling, A. (2003), 'Mayors as actors improving municipal governance', paper presented at the European Group of Public Administration Annual Conference, Lisbon, 3-6 September.

Sheehy, E. (2003), 'City and County Management' in M. Callanan and J.F. Keogan (eds.), Local Government in Ireland: Inside Out, pp.123-142, Dublin: Institute of Public Administration.

Svara, J.H. (1990), Official Leadership in the City: Patterns of Conflict and Cooperation, Oxford; Oxford University Press.

Swift, N. (2003), 'Mayors play the central role in US municipal government', City Mayors, US Local Government, www.citymayors.com, July.

United Kingdom (1998), Modern Local Government: In Touch with the People, Department of the Environment, Transport and the Regions, Cm. 4014, London: Her Majesty's Stationery Office.

Wilson, D. and Game, C. (2006), Local Government in the United Kingdom (4 ${ }^{\text {th }}$ edition), Houndmills, Basingstoke: Palgrave Macmillan.

Zimmerman, J. (2006), 'Executive-Council Relations in England and Ireland', Current Municipal Problems, Vol.33, No.2, pp.196-225. 